\title{
Befuddling Executive Power with Executive Unilateralism in the Unitary Executive*
}

\author{
Okyeon $Y_{i} \mid$ Seoul National University
}

I. Fretting over Executive Unilateralism in America
II. Separation of Power, Checks and Balances,
and Executive Power
III. The Unitary Executive in Theory and Practice
IV. Putting Presidency in Perspective: Preliminary Findings
Keywords: executive unilateralism, separation of power, checks
and balances, executive power, unitary executive

\section{ABSTRACT |}

Previous studies dwell on either how the U.S. Constitution supposedly envisions the conduct of policymaking between the president and Congress, or why the executive branch persistently outmaneuvers Congress. Yet insufficient attention is paid to the fact that the unitary executive is for the purpose of exacting collective decision-making between the two branches of government. This paper is a preliminary endeavor to put American presidency in perspective. In outlining the constitutional foundation of the unitary executive theory, I trace the sources of executive power in the context of separation of powers, and checks and balances as its functional mechanism. Then, I look into the evolving conduct of modern presidents to explore how executive power is often befuddled with executive unilateralism ever since America was built on the principle of presidentialism. By illuminating how some entrepreneurial presidents managed to expand their claims on prerogative powers, I argue that the precedents set by their predecessors in combination with their use of rhetoric unwittingly enable them to justify executive unilateralism at times. I conclude by stipulating whether Barack Obama can overcome the presidency of George W. Bush, by constructing his own version of the unitary executive yet refraining from the entrapment of executive unilateralism.

* An early draft of a minor portion of this paper was presented at the 44th ASAK International Conference, October 23rd, 2009, Seoul, South Korea. This work was supported by the National Research Foundation of Korea Grant funded by the Korean Government (NRF-2010327-B00027). I am grateful for the insightful comments by the anonymous reviewer(s). 


\section{Fretting over Executive Unilateralism in America}

Ikenberry et al. posed a question whether George W. Bush was an heir to Wilson in the twenty-first century, or whether his presidency and the so-called neoconservatives hijacked the liberal internationalism in the name of presidential prerogatives to preserve American democracy.1) Godwin earlier echoed his bewilderment over a persistent gap, if not hypocrisy, between the abstract principles such as liberty and equality that are proudly touted and the concrete policies that often contradict such lofty ideals.2) Though both of their accounts are substantiated by a selective sample of presidents, such a poignant reflection does not explain why presidents manage to succeed in insisting on their own ways, even against Congress. Page and Bouton, in puzzling over the disconnection between the American leaders and the public, partly provide an answer to this question on the basis of differences in policy goals that are pursued. But they stop short of answering the question which boils down to the unitary executive and its variant executive unilateralism.3) In particular, many scholars continue to poke around the so-called doctrine of practical idealism to squeeze out their own interpretation in deciphering American foreign policy, yet they fail to account for why such contradictions have persisted ever since the Founding Fathers painstakingly decided for presidentialism. In this paper, I delineate presidentialism

1) John Ikenberry et al., The Crisis of American Foreign Policy: Wilsonianism in the Twenty-first Century (Princeton: Princeton University Press, 2011), Kindle edition.

2) Jack Godwin, The Arrow and the Olive Branch: Practical Idealism in U.S. Foreign Policy (Westport: Praeger, 2007), Kindle edition.

3) Benjamin I. Page and Marshall M. Bouton, The Foreign Policy Disconnect: What Americans Want from Our Leaders but Don't Get (Chicago: University of Chicago Press, 2006), Kindle edition. Page and Bouton, instead, pursue the question from the perspective of ordinary constituents and contend that public opinion in foreign policy is remarkably consistent and stable despite limits in attention and knowledge observed. Although their extrapolation on the "foreign policy disconnect" points to the principled differences, they aim to demand for more responsiveness on the part of decision makers instead. 
in theory and practice and its source of perpetual controversy surrounding executive unilateralism. In so doing, I partially concur that the unitary executive indeed precipitates a purposive system of befuddling executive power with executive unilateralism. However, I beg to disagree that the unitary executive, by and in itself, is destined to lead to such a misconstruction. I argue that the unitary executive is designed to press for collective decision-making between the two branches of government mandated to govern. In fact, presidents extort such forcible demand precisely because they feel compelled to and get away with it. Some brave ones chose wisely while other brazen ones made a poor choice, that's what makes a difference. This paper is a preliminary endeavor to put American presidency in perspective.

For the Founding Fathers who were determined to replace the malfunctioning Articles of Confederation with the new Constitution, creating political institutions strong enough to mediate effectively between contending social interests ultimately for the sake of the public interest for all yet so weak not to tyrannize the people at the same time was their primary task. In accordance with the letter and spirit of presidentialism, the traditional interpretation of presidentialism was built on the fundamental consensus among three branches that the Constitution cannot be violated with regard to its specific restrictions, that Congress, if willing to, can legitimately assert its role in foreign policy, that the Constitution, although treating it loosely, still governs foreign policy as much as domestic policy, and that occasional and temporary exceptions to the rules, when constrained, are permitted but the rules themselves are never challenged. ${ }^{4)}$ Consequently, until the First World War, presidents - at least in principle - subscribed to restrictions imposed by the Constitution, thus accepting that the legislature has a legitimate role both in foreign and domestic affairs even though it may be persuaded

4) Gordon Silverman, Imbalance of Powers: Constitutional Interpretation and the Making of American Foreign Policy (Oxford: Oxford University Press, 1997), p. 8. 
or bullied into submission by the executive at times.

Then came the much debated post-World War I changes such that exceptions became rules, that is, extraordinary times requiring extraordinary measures were routinized, and recently even degenerated into what are often dubbed as the "perfect storm" convergence or "Madison' nightmare": a prerogative interpretation of the Constitution by the executive, acquiescence to such a prerogative by Congress, and constitutional support by the Supreme Court.5) Accordingly, the ultimate question often comes down to precisely how the Constitution envisions the conduct of policymaking between the president and Congress. To much surprise, legislature is assigned first and thus senior to the Presidency, including the executive branch, when it comes to the order of placement in the Constitution. Yet it should be noted that such a deliberate arrangement is for the purpose of collective decision-making between the two branches both in domestic and foreign affairs rather than the opposition to the unitary executive per se. To put it more bluntly, I contend that the Founding Fathers might have intended a margin for the successive presidents to misconstrue the unitary executive only to invite challenges from all sides in order to force a perennial deliberation. Many of previous research apparently miss this critical juncture, which may fundamentally account for why presidents can act the way they do, often against their critiques. Instead, a bulk of previous works resort to the idiosyncrasy of individual presidency and strive to explain away a pattern of executive audacity.

In this paper, I first outline the constitutional foundation of the oftcalled unitary executive theory. In doing so, I trace the claims of executive power in the context of separation of powers, and checks and balances

5) Silverman (1997), p. 213. Quoting Madison in Federalist 37, Silverman argues for the "deliberate balance" so as to combine "the requisite stability and energy in government with the inviolable attention due to liberty and to the republican form" (phrases in bold are the author's addition). Madison indeed cautions against "a misfortune $\cdots$ that public measures are rarely investigated with that spirit of moderation" even as he opens Federalist 37 by stating that "[I]n reviewing the defects of the existing Confederation, and showing that they cannot be supplied by a government of less energy ..." 
as its functional mechanism. It is of special interest to look into the evolving conduct of modern presidents in the ensuing chapter so that I explore how executive power is befuddled with executive unilateralism. Ever since Andrew Jackson won the $7^{\text {th }}$ presidency on a newly formed party system in 1828 , about half of the presidents claimed a mandate and worked to change the national policy agenda during presidency. In fact, every presidential election was and still is about change of some sort; nevertheless, it is one thing to win a presidential election and quite another to claim a mandate during the presidency.6) Yet, most recently, George W. Bush, even though he did not claim a mandate in his first inaugural address as he failed to win a plurality - not to speak of a majority - of the popular vote, went on an extensive public tour, one of the most massive PR campaigns in American history of presidency, on his touted prerogative powers of the presidency. However, in the aftermath of the terrorist attack and the subsequent Iraq War, George W. Bush dared into a mandate claim during his second inaugural speech. Contrarily, Barack Obama, in the midst of crises within and without, won both a plurality of the popular vote and the electoral-college vote, and as expected, claimed a mandate and started to set the national agenda on behalf of his priority initiatives shortly after taking office. Yet it remains to be seen whether Barack Obama can indeed dissipate the unprecedented controversy surrounding presidential power, if not the presidency of George W. Bush itself, or he himself may succumb to the temptation to usurp it for the sake of national interest as his predecessor vigorously did. I conclude by proposing to put presidency in perspective, if pundits are to contribute to the study of presidentialism.

6) Michael Genovese, "Foundations of the Unitary Executive of George W. Bush," in Ryan Barilleaux and Christopher Kelley (eds.), The Unitary Executive and the Modern Presidency (College Station: Texas A\&M University Press, 2010), p. 130. 


\section{Separation of Power, Checks and Balances, and Executive Power}

Unlike express powers explicitly enumerated in the Constitution, implied powers of the legislative branch are grounded on the constitutional basis, the so-called elasticity clause, while inherent powers of the executive branch derive from the innate nature of the national government that has the same authority to deal with other nations as if it were the central government in a unitary system. ${ }^{7)}$ Albeit its claim based on a constitutional basis, Congress is granted neither formal nor express authority regarding its implied powers by the Constitution. Though dubious, inherent powers of the executive branch are derived from the loosely worded Article II, Section 1 and further defined by practices rather than statutes. In contrast to Article I, Section 1 that limits legislative powers as "herein granted," Article II, Section 1, therefore, is argued to provide a much stronger constitutional basis for inherent powers of the executive branch, in general, and President, in particular.8) $<$ Table $1>$ first compares express powers across legislative and executive branches as laid out in the Constitution, and then contrasts implied powers of the legislative branch with inherent powers of the executive branch.

When Congress clashes with President, however, implied powers of Congress - specifically, congressional oversight and investigation are often rebuffed by inherent powers of President such as executive orders and executive privilege loosely worded in the Constitution as "[T]he executive power shall be vested in a President."9) Contrarily,

7) Article I, Section 8, Clause 18 states that "[T] o make all Laws which shall be necessary and proper for carrying into Execution the foregoing Powers, and all other Powers vested by this Constitution in the Government of the United States, or in any Department or Officer thereof" (phrases in bold are the author's addition).

8) Article I, Section 1 states that "[A]ll legislative Powers herein granted shall be vested in a Congress of the United States, which shall consist of a Senate and House of Representatives."

9) Kenneth Mayer, "Executive Orders," in Joseph Bassette and Jeffrey Tulis (eds.), The Constitutional Presidency (Baltimore: The Johns Hopkins University Press, 2009), p. 150; 


\section{〈Table 1〉Express vs. Implicit Powers between Executive and Legislative Branches}

\begin{tabular}{|c|c|c|c|c|c|c|}
\hline & \multicolumn{3}{|c|}{ Legislative } & \multicolumn{3}{|c|}{ Executive } \\
\hline \multirow[b]{2}{*}{$\begin{array}{c}\text { EX- } \\
\text { PRESS }\end{array}$} & Domestic & Foreign & Encompassing & Domestic & Foreign & Encompassing \\
\hline & $\begin{array}{l}\text { - Levy taxes/ } \\
\text { borrow } \\
\text { money } \\
\text { - Regulate } \\
\text { commerce } \\
\text { - Make } \\
\text { monetary } \\
\text { policy, incl. } \\
\text { coin money } \\
\text { - Establish } \\
\text { federal } \\
\text { courts } \\
\text { below the } \\
\text { Supreme } \\
\text { Court } \\
\text { - Establish a } \\
\text { postal } \\
\text { system } \\
\text { - Impeach } \\
\text { federal } \\
\text { officials (H) } \\
\text { \& try and } \\
\text { remove } \\
\text { them from } \\
\text { office (S) }\end{array}$ & \begin{tabular}{|l} 
- \\
Declare \\
- Raise an \\
army, \\
a navy, \\
incl. call up \\
the state \\
militias \\
- Ratify \\
treaties (S) \\
- Advise \& \\
consent \\
presidential \\
nominations \\
(S)
\end{tabular} & $\begin{array}{l}\text { - Make all } \\
\text { laws that are } \\
\text { "necessary } \\
\text { \& proper" } \\
\text { for } \\
\text { executing } \\
\text { other } \\
\text { powers }\end{array}$ & $\begin{array}{l}\text { - Require } \\
\text { the opinion } \\
\text { of the } \\
\text { principal } \\
\text { officers of } \\
\text { the executive } \\
\text { departments } \\
\text { - Nominate } \\
\text { federal } \\
\text { judges, } \\
\text { public } \\
\text { ministers } \\
\text { \& appoint } \\
\text { Recommend } \\
\text { measures } \\
\text { to Congress } \\
\text { - Fill } \\
\text { vacancies } \\
\text { in the } \\
\text { admin. } \\
\text { during } \\
\text { the Senate } \\
\text { recess } \\
\text { - Convene } \\
\text { Congress } \\
\text { \& adjourn } \\
\text { Congress } \\
\text { if both } \\
\text { houses } \\
\text { disagree } \\
\text { on time } \\
\text { - Veto } \\
\text { legislation }\end{array}$ & $\begin{array}{l}\text { - Commander- } \\
\text { in-chief of } \\
\text { the armed } \\
\text { forces } \\
\text { - Make } \\
\text { treaties } \\
\text { - Nominate } \\
\text { ambassadors } \\
\text { \& appoint } \\
\text { - Receive } \\
\text { ambassadors }\end{array}$ & $\begin{array}{l}\text { - Take care } \\
\text { that laws } \\
\text { be faithfully } \\
\text { executed } \\
\text { - Preserve, } \\
\text { protect, and } \\
\text { defend the } \\
\text { Constitution }\end{array}$ \\
\hline \multirow[b]{2}{*}{$\begin{array}{c}\text { IM- } \\
\text { PLICIT }\end{array}$} & \multicolumn{3}{|c|}{ Implied [legislative] } & \multicolumn{3}{|c|}{ Inherent [executive] } \\
\hline & \multicolumn{3}{|c|}{$\begin{array}{l}\text { - Congressional oversight } \\
\text { - Congressional investigation }\end{array}$} & \multicolumn{3}{|c|}{$\begin{array}{l}\text { - Executive order } \\
\text { - Executive privilege }\end{array}$} \\
\hline
\end{tabular}

David Crockett, "Executive Privilege," in Bassette and Tulis (2009), p. 203. An executive order refers to "a specific document published in the Federal Register in that form or $\cdots$ any unilateral presidential decision or policy." Executive privilege is "the power of a president to withhold information, whether from Congress, the courts, or the public." 


\section{〈Table 2〉 Checks and Balances across Executive, Legislative, and Judiciary Branches}

\begin{tabular}{|c|c|c|c|}
\hline & Legislative & Executive & Judiciary \\
\hline Legislative & & $\begin{array}{l}\text { - Overrule legislative veto } \\
\text { ( } 2 / 3 \text { required) } \\
\text { - Control appropriations } \\
\text { - Control by statute } \\
\text { - Impeach the President } \\
\text { (H) } \\
\text { - Remove the President } \\
\text { (S) } \\
\text { - Approve presidential } \\
\text { appointments (S) } \\
\text { - Ratify treaties (S) } \\
\text { - Committee oversight } \\
\text { - Hold investigative \& } \\
\text { legislative hearings } \\
\text { - Issue subpoena } \\
\text { - Hold executive officers } \\
\text { in contempt }\end{array}$ & $\begin{array}{l}\text { - Control appropriations } \\
\text { - Create inferior courts } \\
\text { - Add new judges } \\
\text { - Approve appointments } \\
\text { (S) } \\
\text { - Impeach judges (H) } \\
\text { - Remove judges (S) }\end{array}$ \\
\hline Executive & $\begin{array}{l}\text { - Veto legislation } \\
\text { - Convene special session } \\
\text { - Adjourn Congress when } \\
\text { both chambers disagree } \\
\text { on time } \\
\text { - VP, presiding over the } \\
\text { Senate \& breaking ties }\end{array}$ & & - Appoint judges \\
\hline Judiciary & $\begin{array}{l}\text { - Judicial review of } \\
\text { legislation } \\
\text { - Chief justice, presiding } \\
\text { over Senate during } \\
\text { proceedings to impeach } \\
\text { the president }\end{array}$ & $\begin{array}{l}\text { - Judicial review of } \\
\text { presidential actions } \\
\text { - Issue warrants } \\
\text { - Chief justice, presiding } \\
\text { over impeachment of } \\
\text { the president }\end{array}$ & \\
\hline
\end{tabular}

the traditional interpretation of the Constitution in the conduct of domestic and foreign affairs revolved around its primary concern over vertical separation of powers for the sake of the balance of energy - normally associated with an active president - and stability - often associated with a consistent legislature. In other words, the court was traditionally 
concerned with national power either because the power of the national government acting together could conflict with the claims of individual rights, or because the power of the national government as a whole might be usurped from powers that were not explicitly delegated to it or reserved to the states. $<$ Table $2>$ delineates checks and balances between executive, legislative, and judiciary branches.

The court initially had two options in interpreting national power, either by reading the Constitution as a unitary document, or by reading the Constitution differently in breach of the traditional interpretation. By choosing the first interpretation, the court often found authority for a strong government both in foreign and domestic affairs by contending that an expansive foreign affairs power should provide for an expansive domestic affairs power.10) The court could alternatively have found authority for a weak and decentralized government both in foreign and domestic affairs. However, this alternative perspective never gained any serious support mainly because the Articles of Confederation was abandoned precisely for the sake of a better and more effective national policy, both in the domestic and foreign realm. By reading the Constitution as a unitary document, therefore, the court traditionally opted for striking down disputes in the conduct of domestic and foreign affairs on the basis of the excessive exercise of power by the government in violation of individual rights, or the improper enactment or policy execution. In so doing, the focus was on the question of whether national government as a whole, i.e. Congress and the president, had the authority in the conduct of domestic and foreign affairs, rather than the presidency in opposition to Congress. Therefore, the court arguably contributed to this gradual but steady change in the perception of unilateral presidentialism.

10) As a consequence, executive orders or presidential directives which require or authorize some action within the executive branch, sometimes extending beyond the government, thus creating or modifying laws and procedures, often became targeted by Congress to probe the appropriate limits of the executive's independent power. 
Interestingly, there were some variations to the traditional interpretation of national power, which vested broad powers to make both domestic and foreign policy possible and excluded the states from such policy control. Even though the question of to what extent the powers were to be actually granted arose constantly, it should be noted that the power of the government was fundamentally limited. ${ }^{11)}$ Nevertheless, primarily because it was poorly equipped to determine exactly what was prohibited and why, the Constitution as a unitary document eventually furnished central power in domestic affairs with national government. Furthermore, because the Constitution as a unitary document delegated restricted powers to the national government, it also sanctioned pragmatic exceptions to foreign and domestic realms alike.12)

What is noteworthy is that the court initially removed itself from foreign affairs realm, in particular; it did so by arguing either that foreign policy was beyond judicial competence or that the Constitution left some issues to be resolved by the elected branches of the government. In other words, instead of choosing between a broad constitutional interpretation and a traditional one, the court sometimes refused to rule on the foreign policy case entirely by invoking the political-question doctrine and returning it to the political system.13) However, United States $v$. Curtiss-Wright Export Corp. (1936) drove the court to interpret national

11) Thus even when national security was argued to be at stake, the executive powers delegated to the president by the Constitution was not unlimited as in the case of Little v. Barreme (1799). A Danish ship, sailing from a French port, was captured by applying the law in which Congress authorized the seizure of American ships suspected of sailing to French ports. The Marshall court ruled that the order of a superior officer was not a defense for violations of law. Thus the captain who ordered the capture was held responsible for such an illegal act even though he insisted that he simply followed orders.

12) Interestingly, the court ruled that there was no logical way to limit pragmatic exceptions to the foreign policy realm alone.

13) In Oetjen v. Central Leather Co.(1917), the court ruled that the national government's power of recognition was a power of the political branches of the national government, thus not subject to judicial review. The court framed foreign policy cases as prototypical political questions yet remained unwilling to accept that all foreign policy cases were inherently beyond the reach of the court. 
power by reading the Constitution differently in breach of the traditional interpretation. 14) Accordingly, the court increasingly found authority separately for a strong government in foreign policy from a source outside the Constitution, and a weak and decentralized government for domestic policy in accordance with the Constitution. ${ }^{15)}$ Especially where the Constitution was found silent on the foreign policy realm, the court found it necessary to separate domestic and foreign affairs, thus protecting "national unity and power abroad" without sacrificing "local control and popular sovereignty at home" at the same time.16)

As a consequence, while the traditional interpretation merely refuted the conventional view that presidential power largely lay in the power to persuade, the contemporary interpretation increasingly regarded presidential power as a matter of prerogative or legal rule, often at the expense of congressional power. ${ }^{17}$ ) The court's role in standing by presidents who invoke claims to prerogative powers in the conduct of domestic and foreign affairs beyond the reach of the states was one thing. However, it was quite another that presidents chose to embrace wholeheartedly the prerogative interpretation of the Constitution, first in the rhetoric by displaying their commitment, and then in the actions by setting precedents.

14) The court ruled that the foreign affairs power were vested in the national government as a whole, and that the President of the United States had "plenary" powers in the foreign affairs independent of congressional delegation. Additionally, the power to conduct foreign relations was not a state power but a power inherent in national sovereignty such that the states could not delegate nor restrict it through the Constitution. In other words, the power to conduct foreign policy was extra-constitutional, thus not requiring affirmative grants of power from the Constitution. By proclaiming foreign affairs powers as inherent not delegated by the Constitution, therefore, the court literally put the national authority in foreign affairs beyond the reach of the states.

15) It was on the basis of contention that the Constitution failed to distinguish explicitly between its applicability in foreign and domestic spheres, on the one hand, and by citing a practical difficulty in dividing foreign and domestic affairs neatly, on the other hand.

16) Silverman (1997), p. 38.

17) For details on the power of persuasion, refer to Richard Neustadt, Presidential Power and the Modern Presidents: The Politics of Leadership from Roosevelt to Reagan (New York: Free Press, 1990). 
Barilleaux and Kelley argue that the unitary executive theory draws from three sources in Article II of the Constitution, especially in contrast to Article I and Article III: "vesting" clause, "oath" clause, and "take care" clause. 18) In Article I, the "legislative" power is qualified; that is, Congress can exercise the "legislative" power, which is limited to those listed in Article I. Article III states that the "judicial" power is divided between the Supreme Court and inferior courts. In contrast, Article II simply states that the "executive" power is explicitly granted to the president. Furthermore, Article II states that presidents take oath to protect the Constitution; that is, presidents can independently challenge provisions of law which they determine to be unconstitutional. This claim of the presidential privilege is indeed written into the design of the Constitution, which, in the absence of a clear ruling by the Supreme Court, shields presidents from enforcing laws if presidents make an independent judgment about their constitutionality. ${ }^{19)}$ In Article II, the president is also mandated to ensure that the laws are "faithfully" executed with assistance from inferior executive branch officers. Accordingly, presidents execute the law personally while monitoring whether the agencies of the executive branch "faithfully" execute the laws. Especially when the Congress cannot possibly monitor every aspect of the executive branch, presidents can and do pull important policy closer to their own palate. Genovese also argues that the unitary executive consists of seven parts:

1) executive prerogative, based on Locke's Second Treatise,

2) "energy" in the executive, grounded on Hamilton's The Federalist Papers, No. 49,

3) the executive power fused with the command-in-chief clause,

18) Ryan Barilleaux and Christopher Kelley, "Introduction: What is the Unitary Executive?" in Barilleaux and Kelley (2010), pp. 3-4.

19) For details, refer to James Madison, "Method of Guarding against the Encroachment of Any One Department of Government by Appealing to the People through a Convention," The Federalist Papers, no. 49. 
4) the doctrine of "necessity," as practiced by Lincoln during the Civil War,

5) supportive court decisions,

6) the "constitutional dictatorship," and

7) the precedents of presidents themselves. ${ }^{20)}$

In the following chapter, I will illuminate the modern presidency by relying on Barilleaux and Kelley's, and Genovese's analysis to account for how presidents increasingly argued that executive power was constitutionally theirs, thus they could act on them without congressional participation. This reconstruction of chronological presidency can enhance our understanding why some presidents chose to rule the way they did. After all, the unitary executive is what presidents make of it with the use of rhetoric as a flavor enhancer; some succeeded while others either tried and failed, or dawdled.

\section{The Unitary Executive in Theory and Practice}

As the Constitutional Convention was about to be concluded in 1787, one of the first Anti-Federalist writers published his objections to the Constitution, especially Article II, in the New York Journal under the pseudonym of Cato. In his fourth letter, Cato vehemently attacked the newly established presidency and its unitary nature along with its strong powers. Roused by fears of a powerful monarchy, Patrick Henry, Governor of Virginia and one of the signers of the Articles of Confederation, concurred with Cato that "... [A]mong other deformities, it has an awful squinting; it squints toward monarchy. And does this not raise indignation

20) Genovese (2010), pp. 130-141. 
in the breast of every American?"21) Although advocates of the unilateral presidentialism claim that the unitary executive in theory was first established at the Constitutional Convention in 1787 and later put into practice in the Washington presidency, it is largely agreed that the Regan administration initiated the unitary executive theory with which we are now familiar.22)

The first generation of enthusiasts, however, immersed themselves in the rhetoric of presidential prerogatives, but fell short of acting on them. Theodore Roosevelt, for instance, was unwilling to act on a reinterpretation of the Constitution even though he insisted on the need for "energy" in the executive "unless such action was forbidden by the Constitution or by the laws." His intention lied in broadening the use of executive power, not usurping power as president, since he was eager to assert national authority in the face of state autonomy. He believed that national authority should not be limited to those explicitly delegated by the Constitution. To him, the real battle raged between advocates of a strong nation and advocates of decentralized authority. ${ }^{23)}$ Therefore, he articulated his version of presidency on the basis of a new interpretation of executive power yet never acted on his own interpretation.

Theodore Roosevelt's successor, William Taft, also argued that the

21) Michael Nelson, (ed.), The Evolving Presidency: Landmark Documents, 1787-2008, 3rd ed. (Washington, D.C.: CQ Press, 2008), p. 19. Phrases emphasized in block are the author's addition.

22) Jess Bravin, "Judge Alito's View of the Presidency: Expansive Powers," Wall Street Journal, Jan. 5th, 2006, A1. Reagan came to office after the so-called "imperial presidency" in the Nixon administration practically nullified the Ford and Carter presidencies as Congress increasingly asserted its powers. Determined to rejuvenate the ailing presidency, Reagan aggressively developed a constitutional theory of presidential unilateralism, aiming to "reinterpret the scope of executive power and the limits to congressional authority.

23) Lance Robinson, "Theodore Roosevelt and William Howard Taft: The Constitutional Foundations of the Modern Presidency," in Bassette and Tulis (2009), p. 78. Even when Theodore Roosevelt managed to act, he would either cajole support from Congressmen by employing his political skills within clearly constitutional powers, or if Congress was unresponsive, he did force his way although he acknowledged that only Congress could make any presidential action into law as in the case of the Santo Domingo treaty, which was a precedent for the use of executive agreements. 
president's legitimate authority was not confined to express congressional statutes and provisions but encompassing the areas where Congress failed to act, although subjected to limits to presidential autonomy. Like Roosevelt, Taft concurred that all power in foreign affairs, in particular, was exclusively vested in the national government. Taft's victorious opponent, Woodrow Wilson, too, accepted that the exercise of extraordinary powers was derived from congressional statutes, not from vague constitutional phrases nor sanctioned after the fact. ${ }^{24)}$ Although he wanted to distinguish between the outmoded forms and procedures growing out of the Constitution, and the principles embedded in the document, he acknowledged that the legislature had the final power to decide on most presidential initiatives. ${ }^{25)}$ Even Franklin Roosevelt, who served 4 consecutive terms, strove to gain broad executive powers and authority from congressional statutes, not from a loose construction of the Constitution.26) Even when lodging bitter complaints against the recalcitrant Congress, he opted to mobilize the supportive public on his side rather than resort to a reinterpretation of the Constitution and thus the emergency powers of legislation. Moreover, he rested his authority on executive precedents,

24) William Taft, $27^{\text {th }}$ President, also served as the $10^{\text {th }}$ Chief Justice in 1921 by President Harding. Taft drove his predecessor, Theodore Roosevelt, out of the Republican Party in a nomination process; Theodore Roosevelt consequently ran as the Progressive "Bull Moose" Party candidate in 1912. Taft ultimately got defeated by the Democrat, Woodrow Wilson.

25) Woodrow Wilson, Constitutional Government in the United States (New York: Columbia University Press, 1908/1961), p. 77. By using the party machinery and his ability to influence public opinion, Wilson hoped to exercise his power against a recalcitrant legislature but rejected the idea that the president could simply ignore Congress. His idea of an aggressive presidency and an assertive executive leadership was based on his conviction that the president should not be above the law but instead rise above confrontation of political skills. Yet in confrontation with the directly elected Senate in the foreign policy realm, his insistence on an aggressive presidency flared up into personal obsession with presidential mandates on the conduct of foreign affairs. "One of the greatest of the President's powers I have not yet spoken of at all: his control, which is very absolute, of the foreign relations of the nation..."

26) Even though the Constitution was arguably designed to change with the times and adapt to the needs of the country, FDR acted on statutory authority during the World War II, for instance. 
not on Congress, thus bordering on a prerogative argument. In case of congressional inaction, all he needed to do was a threat of autonomous actions, i.e. executive unilateralism.27)

What is noteworthy is that FDR's rhetoric of extraordinary powers, which he himself never acted on, offered a precedent for future presidents. Especially in situations short of emergency, later presidents could and did assert these powers and further actively exercised them, often as legitimate constitutional powers rather than as temporary aberrations. Harry Truman, for instance, rested authority on dual grounds, by invoking the constitutional authority in line with the traditional rhetoric while building a new constitutional rhetoric on the broad mandate of Article II and on the commander in chief clause in the Constitution, in the case of foreign affairs, in one breath. He defied the temporary emergency claims when pursuing constitutionally suspect actions, but he sought statutory authority in accordance with the traditional interpretation. Interestingly, many legislators strongly opposed claims on presidential prerogatives, but few actually voted against the actual policy.28) That is, Congress remained supportive of the general policy in practice, even though they found the process by which the president achieved it troublesome in theory. This, in effect, made it possible for Truman to further stretch his political muscles, both in the realm of domestic and

27) So, he did not need to act on his rhetoric of constitutional prerogatives since Congress immediately debated price stabilization measures on farm products when confronted with his threat of unilateralism.

28) Bryan Marshall and Patrick Haney, "Aiding and Abetting: Congressional Complicity in the Rise of the Unitary Executive," in Barilleaux and Kelley (2010), p. 192. For instance, Truman identified coal strikes with "a strike against the Government" because of their threat to numerous industries, including the nation's rail system. Thus he approached Congress for a radical legislation authorizing the president to seize profits, to order union leaders not to interfere, to strip them of seniority and penalize them criminally if they refuse to return to work, and to draft all workers on strike into the armed forces so as to subject them to military court martial and punishment. Upon his request, legislators began to articulate the prerogative argument although the strike control bill ultimately died with the settlement of strikes, thus becoming receptive to the idea that "extraordinary times call for extraordinary powers." 
foreign affairs.

The conventional wisdom is that presidential powers were previously limited to his ability to persuade Congress and the public on exceptions, which meant that political battles were fought for congressional and public support. However, it became obliterated since the 1950s such that the burden of demonstrating the legitimacy now shifted from the president to Congress, which now must formally and unequivocally prohibit him from extraordinary actions. Truman's seizure of the steel mills and its reversal clearly illustrates how such precedents over claims on presidential prerogatives could and did at times serve Truman himself and any future president well.29) However - and fortunately for the sake of preserving the foundation of the unitary executive, the court stroke it down by ruling that executive authority stood constitutional only if Congress formally delegated the power to seize the mills and Congress rebuked his request to seize the mills by an executive order. ${ }^{30)}$ Although he disagreed with the Court's ruling, he eventually chose to abide by the ruling as a prudent political choice only to be rejected by Congress. Nonetheless, it needs to be noted that Truman never conceded that only the Court had the final word on the presidential privilege of making an independent judgment about the constitutionality of laws. Even in the absence of congressional action or in the face of congressional opposition, Truman argued that the president could act alone, thus actually acting on a new interpretation that neither the courts nor Congress could

29) Kenneth Mayer, "Executive Orders," in Bassette and Tulis (2009), p. 154. After witnessing an expansive presidency and a compliant Congress as well as public over the years, Truman anticipated the public rally to the sole claim to executive authority without an additional traditional argument in accordance with statutory authority.

30) Of the four options, namely 1) force a 90-day cooling-off period by invoking the statutory authority, 2) seize critical defense industries under a complicated process by acting under a statute, 3) go to Congress for explicit seizure authority, 4) seize the mills by executive order, Truman preferred the fourth option because its disadvantage was minimal in comparison with the other three, that is, 1) punish the wrong group, i.e. cooperative labor when the owners are intransigent, 2) a drawn-out process may not prevent the strike on time, 3) hostility between the executive and legislative branches looms on labor issue, and 4) none. 
stop the president from executing prerogative powers. ${ }^{31)}$

Truman's successor - Dwight Eisenhower, in contrast, chose to thoroughly resort to legislative cession of the authority to the executive, thus building prerogative powers through traditional means. Eisenhower was argued to carry a mixed perspective on constitutional prerogatives and thus confined policy backed by the threat of military force to the traditional interpretation or congressional endorsement to avoid entrapment by legislators "who celebrate a policy but denounce its effect," as previously shown in the case of Korean War. ${ }^{32)}$ Legislators, too, delegated extraordinary power to the executive to deploy troops and distribute foreign aid, not only on the basis of their patriotic conviction that a real emergency at the time necessitated extraordinary delegation, but also its political advantage of insulating themselves from policy decisions and their debacles.33) Unlike Eisenhower who sought congressional delegation of broad power to the executive, his successor, John F. Kennedy, preferred to merely brief legislators rather than seek their advice and authorization. By pursuing congressional resolution to contribute to the executive's developing and executing policies, not its resolution to grant the president any authority, Kennedy became convinced that president should be free to set both domestic and foreign policy.34)

Emboldened by the rhetoric of prerogative interpretation and substantiated by precedents, succeeding presidents started to assert executive prerogatives as a sole basis of interpretation. Repeated precedents, in effect, built the authority and legitimacy of the disputed function despite

31) Harry Truman, Public Papers of the Presidents of the United States: Harry S. Truman (Washington, D.C.: GPO, 1965), p. 478.

32) Silverman (1997), p. 76.

33) Congress contributed to the entrenched executive prerogative interpretation by subscribing to the need for the centralized authority in foreign affairs, but only because they sensed Eisenhower's need to lock in the congressional support for military action.

34) According to this logic, Presidents can celebrate a prerogative interpretation of executive powers as a rule not as an exception because they have the power, the authority and the constitutional legitimacy with no need for congressional participation. 
the congressional authority to revoke the precedent or to overturn the previous authorization, because it made politically more difficult to challenge the status quo, no matter how constitutionally suspect. Lyndon Johnson, for instance, acted in concert with Congress, merely because the resolution would affirm the president's decision as a show of unity, not because it authorized or legitimized his action.35) Richard Nixon completed this circle of assertive presidency, if not unilateral presidentialism, when he declared that "foreign policy needs and powers can, should and would dictate domestic priorities and constitutional authority."36) He went on to propagate the legitimacy of precedents in presidential prerogatives on the basis of a long-standing executive assertion and congressional acquiescence. Even when Congress did strike back, Nixon snubbed that it was without binding force or effect.

The Post-Nixon era, therefore, was unfolded in a series of reaction to what Nixon's presidency epitomized and an occasional triumph proclaimed by Congress. Unlike the president who is supposed to represent the entire country, however, members of Congress represent just one of many districts. This discrepancy sometimes leads to a shortcoming in translating election returns into legislative directives. ${ }^{37)}$ Contrarily, presidents enjoy enormous democratic legitimacy, often at the cost of

35) Lyndon Johnson, Public Papers of the Presidents of the United States: Lyndon B. Johnson (Washington, D.C.: GPO, 1967), p. 91. Unlike Eisenhower who used the earned authority as a negotiation tool, Johnson first secured broad powers and authority from Congress, and then implemented such powers and authority, thus upending Congress.

36) Richard Nixon, Public Papers of the Presidents of the United States: Richard M. Nixon (Washington, D.C.: GPO, 1978), p. 382. Nixon justified exercise of executive prerogatives at home because foreign policy needs should give the president the constitutional authority, for instance, to order wiretaps on American citizens at home, to impound funds appropriated by Congress, and to order an extensive surveillance campaign by CIA targeting American citizens and focusing on political activity both at home and abroad. Moreover, he argued that if the Constitution gave the president prerogative in foreign affairs and if the conduct of foreign affairs required the exercise of power at home, then the Constitution authorized such as well. A deadly shooting at the Kent State University in 1970 occurred at the height of Nixon's full-blown prerogative argument.

37) As a consequence, Congress found itself bound to the very chain which it intended to bound the President as in the case of the War Powers Resolution in 1973. 
congressional authority simply because presidents can claim to connect with the people, the entire population, on an emotional level. Although the current centralized executive policymaking is largely criticized in the light of democratic theory, it remains unchanged that the fusion of power, namely head of state and head of government, unquestionably warrants a strong, if not unilateral, presidency. Then it may be inevitable that the president, as the only elected official to represent the entire country, is tempted to claim policy mandates.

In choosing their first African-American President in 2008, many Americans were immensely proud of their accomplishment and accordingly anticipated a better time ahead, which was mutually shared by the rest of the world. Yet Barack Obama inherited a set of circumstances that no world leader in recent periods did. ${ }^{38)}$ Consequently, Obama's transition was intensely scrutinized partly because presidential transition would normally portend what kind of president he would be for the next four years and partly because Obama was elected at an extraordinary time. ${ }^{39)}$ Since then, Barack Obama found himself in a precarious position to seize the opportunity while the stakes remained extraordinarily high, both within and without, especially since the intransigent Republicans took control of the House in the 2010 mid-term election. Moreover, there is consensus that emergency, by and in itself, does not necessarily warrant presidential unilateralism. Shane earlier warned against the "perfect storm" convergence of expansive executive power and partisan aspiration of permanent campaigning for policy dominance on Capitol Hill with

38) Linton Weeks, "Obama is the $44^{\text {th }}$ U.S. President: Now What?" NPR.org (November $4^{\text {th }}$, 2008). Quoting historian Douglas Brinkley, Weeks argued that "the world has gotten so speedy that even though Obama will not be inaugurated until Jan. 20, 2009, people will assume that Obama is the president on Wednesday morning, the day after the election."

39) The outcome of 2008 presidential election was touted to lead to a dramatic change both in domestic and foreign policy. Not surprisingly, America and the rest of the world eagerly pondered on a possible shift in the way domestic and foreign affairs were dealt with. For the past 6 , if not 8 years, George W. Bush was alleged not only to take constitutionally suspect actions but also reinterpret the Constitution under the pretext of executive-prerogative claims with a governing legislative majority. 
the silent — if not compliant — court since 1981. In proposing to dampen such an extreme presidentialism, he argued for the retrieval of constitutional pluralism, which is put into practice. ${ }^{40)}$ There is no doubt that Obama strives to enlist advocates from all sides in diffusing his vision of the unitary executive.

It remains to be seen whether Obama can indeed rise above the controversial presidency of George W. Bush. Yet at the same time, Obama like his predecessors - including George W. Bush - aims to rule with the executive power bestowed upon him. Just as some of his predecessors managed to succeed in making the best out of it, Obama, too, keeps striving to venture out in order to leave behind his own version of the unitary executive simply because he can. Obama's presidency may indeed come out of the other side of history by refurbishing the unitary executive as intended by the Founding Fathers. But then again, their posterity handed down their legacies with good intentions, or so they proclaimed. It is from here that theorists of the unitary executive can present a partial remedy to the executive unilateralism by elucidating why presidents behave the way they do. For that purpose, I propose to put presidency in perspective, which will be pursued in the future research.

40) Shane (2009), p. vii. "Our Constitution was founded on the radical hope that good government design can so constrain the ambitions of public officials as to protect the American public from tyranny and abuse. Instead of constrained ambition, however, Americans have become increasingly accustomed to governmental audacity $\cdots$ [w]e seem to have abandoned checks and balances for something very different. At this point, that "something" looks more and more like a virtually unchecked presidency, nurtured too often in its political aggressiveness by a feckless Congress and obsequious courts $\cdots[T]$ he increasingly assertive claims to unilateral presidential authority, accompanied by the occasional overreaching of the other two branches of government, add up to the subversion of constitutional checks and balances that I have dubbed "Madison's Nightmare." 


\section{Putting Presidency in Perspective: Preliminary Findings}

It still remains debatable whether presidents have a shaky constitutional basis for prerogative claims even though the U.S. Presidency is notably unusual, if not abnormal in comparison with other democracies, in that practically all executive roles and authority are concentrated in a sole office, and thus a single individual.41) Institutionally, however, presidents are insulated from other political players but also held in check by legislative and judicial branches at the same time. Some presidents turned out to be incapable of an effective governing while others even managed to disregard or dominate other political players. Even a few dauntingly could mobilize public opinion to coerce Congress into submission.42) All of the 44 presidents were successfully elected by promising a change of some kind to the people, yet their commonness ended there. What made a difference among presidents who all aspired to leave behind legacy? This is the question to be answered by putting presidency in perspective.

Presidents are normally expected to rise above partisan politics as

41) Raymond Smith, The American Anomaly: U.S. Politics and Government in Comparative Perspective (New York: Routledge, 2008), p. 78. Smith argues further that such a fusion of powers is unlikely to distinguish President as a person from President as an office and that even more problematic is the difficulty to separate the office from the country as shown in the case of Richard Nixon's full-fledged prerogative argument or even the brisk response by the George W. Bush White House staffs to equate questioning the president in times of crisis with the unpatriotic act, if not treason, shortly after September $11^{\text {th }}$, 2001.

42) For details, refer to Samuel Kernell, Going Public: New Strategies of Presidential Leadership (Washington, D.C.: Congressional Quarterly Inc., 1997). Notable examples are Theodore Roosevelt's "bully pulpit," FDR's "fire chat," John F. Kennedy's inaugural speech of "Do not ask what your country can do for you; ask what you can do for your country," and Ronald Reagan's 'going public.' For critiques, refer to George C. Edwards III, On Deaf Ears: The Limits of the Bully Pulpit (New Haven: Yale University Press, 2003), pp. 241-254. Although permanent campaigns necessitated 'going public,' Edwards argues that "the bully pulpit has proved ineffective not only for achieving majority support but also for increasing support from a smaller base," thus advocating "staying private" instead. 
they are mandated to represent national interest as a whole.43) Alternatively, presidents are argued to make mandate claims if political environments contribute to the rhetoric that prioritizes their role as a politician and a party leader over that as a national statesman. ${ }^{44)}$ In the American presidentialism, elections as instruments of democracy are often interpreted as mechanisms for control so that electoral outcomes directly determine who is in charge of policymaking. Accordingly, elections are seen more as mechanisms of signals about popular policy preference than as mechanisms of accountability. In this context, presidents who claim electoral mandates maintain that voters have spoken, that is, voters issued a command. Thus the argument goes that presidents have to abide by this command as he was elected to represent the entire country. ${ }^{45}$ )

The Framers surely intended Congress to represent the people but their intention was not clear whether the presidency, too, was designed to act in concert with the people. They empowered the Supreme Court with judicial review, yet its constitutional ground itself is challenged at times. Moreover, the judiciary branch keeps an arm's length over such political questions. Nonetheless, the popular link behind Andrew Jackson's claim is subjected to scrutiny, both scholarly and politically,

43) Thus a conventional wisdom leads to a logical anticipation that large electoral victories are conducive to mandate claims because presidents can cite their electoral mandate as justification for policy action in the coming years.

44) Okyeon Yi, "A Blind Spot in American Democracy: Separation of Power in Foreign Policy under Presidentialism," Journal of American Studies, Vol. 42, No. 2 (2010), p. 57. As the only person elected by all the people, the president has a national constituency, thus able to claim to speak for the country and often get blamed for national policies as a whole. President also has a partisan constituency so that he has to attend to the active members and leaders of the president's party, even small group of extreme views, because presidents are first nominated in presidential primaries. Once elected, president needs partisan support in Congress, to govern which means it is necessary to obtain the legislative majority. The problem may arise under a divided government in which partisan control of the presidency differs from that of the legislature, which separation of powers, that is, division of power between separate branches aggrandizes.

45) What makes mandate claims even more intriguing is that presidents can and do use the rhetoric of mandates to initiate and implement policy priority, sometimes at odds with Congress which also adopts the rhetoric of mandates in representation. 
largely because rhetorical appeals may beckon presidents to increase the power of his office.46) If the presidency democratizes, the same popular link between the presidency and the people can contribute to the increase in potentials for popular influence at times. As emphasized repeatedly, the use of mandate rhetoric does not warrant an automatic legitimacy of policy action. Yet under the ripe conditions, it may actually surmount opposition to policy initiatives. ${ }^{47)}$ Indeed direct voter influence on policy, for instance, arises when a majority of voters know what they want and make clear to president that they expect him to launch policy action immediately.48) Unfortunately, direct voter policy influence is rare and difficult to achieve. Moreover, president would resist policy partnership when he can clearly take advantage of political conditions conducive to the use of mandate rhetoric instead.

Earlier, Dahl contended that Andrew Jackson created the myth of the presidential mandate, thus justifiably blamed for the 'pseudo-democratization of the presidency.' $\left.{ }^{\prime} 9\right)$ Dahl went on to debunk presidential

46) James Ceasar, "Presidential Selection," in Joseph Bassette and Jeffrey Tulis (eds.), The Presidency in the Constitutional Order: An Historical Examination (New Brunswick: Transactions Publishers, 1981/2010), pp.239-240. Considering that the very idea of electoral mandates originated from that of party mandates by making policy commitments to the electorate, presidents tend to make mandate claims more often when they are reliant on a partisan base for support. After all, by invoking the partisan component of presidential authority, presidential mandates remind the voters that the president's policy priority is grounded on campaign promises. Since the Jacksonian era of democracy, presidents were affiliated with political parties so that they could build their political support base. At the same time, Andrew Jackson claimed that president as the only nationally elected official was the direct representative of the people because he was charged with protecting the broadest public interest.

47) Patricia Heidotting Conley, Presidential Mandates: How Elections Shape the National Agenda (Chicago: The University of Chicago Press, 2001); Congressional Quarterly Guide to U.S. Elections, $6^{\text {th }}$ ed. (Washington, D.C.: Congressional Quarterly Inc., 2009). In fact, the use of mandate rhetoric roughly doubled since Jackson made the first claim although it remains to be seen whether such an increase eventually led to a successful policy action. 9 presidents made mandate claims between 1828 and 1908 while 18 presidents used mandate rhetoric between 1912 and 2008.

48) Bruce Buchanan, The Policy Partnership: Presidential Elections and American Democracy (New York: Routledge, 2004), p. 16. Then, by definition, direct voter policy influence closely replicates the democratic ideal that voter input is directly linked with policy prior to enactment. 
mandates by accusing Woodrow Wilson of his unconstitutional claim that the president as representative of the people is "not merely equal to Congress but actually superior to it."50) During the past 70 years, the Great Depression in the 1930s ushered in New Deal regulation to replace a long-preached laissez-faire economy, followed by the Great Society and civil rights movement in the late 1950s and 1960s which geared the society toward a heavy-handed government. September 11 and its aftermath only aggrandized such urge to reinterpret the Constitution such that the post-911 presidency no longer subscribed to restrictions imposed by the Constitution, if not violating the constitutional limits outright.

Advocates of the executive prerogatives contend that there is sufficient precedent to pursue the unitary executive, both in theory and practice. From Lincoln, Wilson, FDR, to Truman and Kennedy, many of his predecessors strove to ensure security for the sake of democracy by taking a full advantage of their executive power. In doing so, they expanded the executive power, with which Nixon, Reagan, and Clinton attempted to build an assertive presidency mandated to protect democracy both within and without. Yet Nixon culminated the executive unilateralism and proceeded to usurp the so-called crisis presidency, refusing to place himself both as a person and an office within the rule of law. Then came George W. Bush, who proactively publicized his version of the unitary executive by invoking that "the survival of liberty in our land increasingly depends on the success of liberty in other lands" to justify

49) Indeed in his second inaugural address, Andrew Jackson declared that "[t]he will of the American people, expressed through their unsolicited suffrages, calls me before you to pass through the solemnities preparatory to taking upon myself the duties of President of the United States for another term."

50) Robert Dahl, "Myth of the Presidential Mandate." Political Science Quarterly, Vol. 105, No. 3 (1990), pp. 356-7. In his second inaugural address, Woodrow Wilson unequivocally blazoned that "I stand here and have taken the high and solemn oath to which you have been audience because the people of the United States have chosen me for this august delegation of power and have by their gracious judgment named me their leader in affairs." Phrases emphasized in block are the author's addition. 
his actions both in Iraq and inside his homeland.51) How to restore the robust yet accountable presidency, that is the task ahead for the Obama era, which can reflect and shape the American presiden- tialism with its own capacity to interpret the Constitution. This paper took off where previous research left by addressing how some presidents managed to govern their way and get away with it in the conduct of foreign and domestic affairs. By providing preliminary findings from such an inquiry, I hope that this paper may further future study on why presidents behave the way they do in a more systematic way.

51) George W. Bush, in his Second Inaugural address, proclaimed that "We are led, by events and common sense, to one conclusion," as the invasion into Iraq prolonged into a full-fledged war. Earlier in 2001, he coerced Congress into passing the Patriot Act in the aftermath of 9-11 terrorist attacks. This controversial act eased restrictions on surveillance, expanded the Secretary of the Treasury's authority in regulating financial transactions, and broadened the discretion in detaining and deporting immigrants suspected of terrorism-related acts. The reauthorization bill was signed into law in 2006 despite criticism over its ignoring civil liberty concerns. 


\section{[References ]}

Barilleaux, Ryan, and Christopher Kelley. "Introduction: What is the Unitary Executive?" In Ryan Barilleaux and Christopher Kelley (eds.). The Unitary Executive and the Modern Presidency (College Station: Texas A\&M University Press, 2010).

Bravin, Jess. "Judge Alito's View of the Presidency: Expansive Powers." Wall Street Journal, Jan. $5^{\text {th }}, 2006$, A1.

Buchanan, Bruce. The Policy Partnership: Presidential Elections and American Democracy (New York: Routledge, 2004).

Ceasar, James. "Presidential Selection." In Joseph Bessette and Jeffrey Tulis (eds.). The Presidency in the Constitutional Order: An Historical Examination (New Brunswick: Transactions Publishers, 1981/2010).

Congressional Quarterly Guide to U.S. Elections, $6^{\text {th }}$ ed. (Washington, D.C.: Congressional Quarterly Inc., 2009).

Conley, Patricia Heidotting. Presidential Mandates: How Elections Shape the National Agenda (Chicago: The University of Chicago Press, 2001).

Crockett, David. "Executive Privilege.” In Joseph Bessette and Jeffrey Tulis (eds.). The Constitutional Presidency (Baltimore: The Johns Hopkins University Press, 2009).

Dahl, Robert. "Myth of the Presidential Mandate." Political Science Quarterly, Vol. 105, No. 3 (1990).

Edwards III, George C. On Deaf Ears: The Limits of the Bully Pulpit (New Haven: Yale University Press, 2003).

Genovese, Michael. "Foundations of the Unitary Executive of George W. Bush." In Ryan Barilleaux and Christopher Kelley (eds.). The Unitary Executive and the Modern Presidency (College Station: Texas A\&M University Press, 2010).

Godwin, Jack. The Arrow and the Olive Branch: Practical Idealism in U.S. Foreign Policy (Westport: Praeger, 2007). Kindle edition.

Ikenberry, G. John, Thomas J. Knock, Anne-Marie Slaughter, and Tony Smith. The Crisis of American Foreign Policy: Wilsonianism in the Twenty-first Century (Princeton: Princeton University Press, 2011). Kindle edition.

Johnson, Lyndon. Public Papers of the Presidents of the United States: Lyndon B. Johnson (Washington, D.C.: GPO, 1967).

Kernell, Samuel. Going Public: New Strategies of Presidential Leadership (Washington, D.C.: Congressional Quarterly Inc., 1997).

Madison, James. "Method of Guarding against the Encroachment of Any One Department 
of Government by Appealing to the People through a Convention.” The Federalist Papers, no. 49.

Marshall, Bryan, and Patrick Haney. "Aiding and Abetting: Congressional Complicity in the Rise of the Unitary Executive." In Ryan Barilleaux and Christopher Kelley (eds.). The Unitary Executive and the Modern Presidency (College Station: Texas A\&M University Press, 2010).

Mayer, Kenneth. "Executive Orders.” In Joseph Bessette and Jeffrey Tulis (eds.). The Constitutional Presidency (Baltimore: The Johns Hopkins University Press, 2009).

Nelson, Michael (ed.). The Evolving Presidency: Landmark Documents, 1787-2008, 3rd ed. (Washington, D.C.: CQ Press, 2008).

Neustadt, Richard. Presidential Power and the Modern Presidents: The Politics of Leadership from Roosevelt to Reagan (New York: Free Press, 1990).

Nixon, Richard. Public Papers of the Presidents of the United States: Richard M. Nixon (Washington, D.C.: GPO, 1978).

Page, Benjamin I., and Marshall M. Bouton. The Foreign Policy Disconnect: What Americans Want from Our Leaders but Don't Get (Chicago: University of Chicago Press, 2006). Kindle edition.

Robinson, Lance. "Theodore Roosevelt and William Howard Taft: The Constitutional Foundations of the Modern Presidency." In Joseph Bessette and Jeffrey Tulis (eds.). The Constitutional Presidency (Baltimore: The Johns Hopkins University Press, 2009).

Silverman, Gordon. Imbalance of Powers: Constitutional Interpretation and the Making of American Foreign Policy (Oxford: Oxford University Press, 1997).

Smith, Raymond. The American Anomaly: U.S. Politics and Government in Comparative Perspective (New York: Routledge, 2008).

Truman, Harry. Public Papers of the Presidents of the United States: Harry S. Truman (Washington, D.C.: GPO, 1965).

Weeks, Linton. "Obama is the $44^{\text {th }}$ U.S. President: Now What?" NPR.org (November $4^{\text {th }}$, 2008).

Wilson, Woodrow. Constitutional Government in the United States (New York: Columbia University Press, 1908/1961).

Yi, Okyeon. "A Blind Spot in American Democracy: Separation of Power in Foreign Policy under Presidentialism.” Journal of American Studies, Vol. 42, No. 2 (Summer 2010, in Korean). 
[초 록]

\section{단일 행정부체제의 집행권한에 대한 일고}

이옥연 | 서울대학교

미국 대통령제에 대한 기존 문헌은 대체로 미국 연방헌법에 토대를 두는 행정 부와 입법부 간 정책결정 소재지에 관한 논의나 혹은 대통령을 중심으로 하는 행정부가 입법부보다 우위를 선점하는 배경에 초점을 맞춘다. 그러나 정작 단일 행정부체제는 행정부와 입법부 간 집합적 정책결정을 강요하려는 목표를 달성 하기 위해 구상되었다는 사실을 간과한다. 이 논문은 이러한 미비점을 보완하고 자 미국의 통치질서로서 대통령제에 대한 일고를 제안한다. 우선 단일 행정부체 제 이론의 헌법적 토대에 관한 개요를 제시하면서 집행권한의 근원을 권력분립 과 그 작동기제인 균형과 견제의 맥락 속에서 살펴보고자 한다. 그리고 성공적 으로 대권(prerogative powers)에 대한 주장을 관철한 역대 대통령의 족적을 통해 역대 대통령의 선례와 더불어 집행권한을 둘러싼 수사가 결과적으로 행정 부 일방주의를 정당화하는 데 기여했다는 점을 강조하고자 한다. 마지막으로 오바마가 과연 실질적으로 행정부 일방주의의 덫에 빠져들지 않고 전임 대통령 인 조지 W. 부시에 의해 또 다른 선례로 남겨진 논란 많은 대통령제를 넘어서는 새로운 단일 행정부체제를 위업으로 성취할 수 있을지에 대해 전망하며 결론을 맺고자 한다.

주제어: 행정부 일방주의, 권력분립, 균형과 견제, 집행권한, 단일 행정부 체제

투고일: 2011년 1월 24일, 심사일: 2011년 1월 25일, 게재확정일: 2011년 2월 15일 